\title{
A 500 kyr record of global sea-level oscillations in the Gulf of Lion, Mediterranean Sea: new insights into MIS 3 sea-level variability
}

\author{
J. Frigola ${ }^{1}$, M. Canals ${ }^{1}$, I. Cacho ${ }^{1}$, A. Moreno ${ }^{2}$, F. J. Sierro ${ }^{3}$, J. A. Flores ${ }^{3}$, S. Bernéé ${ }^{4,8}$, G. Jouet ${ }^{4}$, B. Dennielou ${ }^{4}$, \\ G. Herrera $^{1}$, C. Pasqual ${ }^{1}$, J. O. Grimalt ${ }^{5}$, M. Galavazi ${ }^{6}$, and R. Schneider ${ }^{7}$ \\ ${ }^{1}$ CRG Marine Geosciences, Department of Stratigraphy, Paleontology and Marine Geosciences, \\ University of Barcelona, Spain \\ ${ }^{2}$ Pyrenean Institute of Ecology, Spanish Research Council, Zaragoza, Spain \\ ${ }^{3}$ Department of Geology, University of Salamanca, Spain \\ ${ }^{4}$ IFREMER Laboratoire Environnements Sédimentaires, Plouzané, France \\ ${ }^{5}$ Department of Environmental Chemistry, Spanish Research Council, Barcelona, Spain \\ ${ }^{6}$ Fugro Engineers B.V., Leidschendam, The Netherlands \\ ${ }^{7}$ Institut für Geowissenschaften, Christian-Albrechts-Universität zu Kiel, Germany \\ ${ }^{8}$ Université de Perpignan Via Domitia, Perpignan, France \\ Correspondence to: M. Canals (miquelcanals@ub.edu)
}

Received: 22 November 2011 - Published in Clim. Past Discuss.: 20 December 2011

Revised: 16 April 2012 - Accepted: 18 May 2012 - Published: 22 June 2012

\begin{abstract}
Borehole PRGL1-4 drilled in the upper slope of the Gulf of Lion provides an exceptional record to investigate the impact of late Pleistocene orbitally-driven glacioeustatic sea-level oscillations on the sedimentary outbuilding of a river fed continental margin. High-resolution grainsize and geochemical records supported by oxygen isotope chronostratigraphy allow reinterpreting the last 500 ka upper slope seismostratigraphy of the Gulf of Lion. Five main sequences, stacked during the sea-level lowering phases of the last five glacial-interglacial 100-kyr cycles, form the upper stratigraphic outbuilding of the continental margin. The high sensitivity of the grain-size record down the borehole to sealevel oscillations can be explained by the great width of the Gulf of Lion continental shelf. Sea level driven changes in accommodation space over the shelf cyclically modified the depositional mode of the entire margin. PRGL1-4 data also illustrate the imprint of sea-level oscillations at millennial time-scale, as shown for Marine Isotopic Stage 3, and provide unambiguous evidence of relative high sea-levels at the onset of each Dansgaard-Oeschger Greenland warm interstadial. The PRGL1-4 grain-size record represents the first evidence for a one-to-one coupling of millennial time-scale sealevel oscillations associated with each Dansgaard-Oeschger cycle.
\end{abstract}

\section{Introduction}

Sea level oscillations of about $120 \mathrm{~m}$ of amplitude paralleled the orbitally-driven 100-kyr climate cycles of the late Pleistocene in response to global ice volume changes (Imbrie et al., 1992; Siddall et al., 2006). Jointly with sediment input and subsidence, these sea-level oscillations controlled the stratal geometry of passive continental margins where migration of fluvial-influenced deposits generated regressive/transgressive depositional sequences. The seismostratigraphic study of those stacked sequences can help to develop the linkage between sea-level fluctuations and sedimentary unit deposition once the seismic interpretation is placed in a sequence stratigraphy framework (Posamentier and Vail, 1988; Vail et al., 1977). More refined sea-level curves based upon benthic and planktic oxygen isotopes in marine sediment cores, in some cases corrected for temperature variations, and dated uplifted coral terraces have been published during the last decade (Chappell, 2002; Miller et al., 2005; Rohling et al., 1998, 2009; Shackleton et al., 2000; Siddall et al., 2003; Thompson and Goldstein, 2005, 2006; Waelbroeck et al., 2002; Yokoyama et al., 2001). However, intrinsic limitations of sea-level reconstruction methods and limitations of obtaining better and more precise age control of marine

Published by Copernicus Publications on behalf of the European Geosciences Union. 
records make difficult the task to accurately constrain orbital and millennial time-scale sea-level fluctuations. Thus, continental margin sedimentary records consisting of depositional units characterised with very high sedimentation rates and precise chronology could provide a better time control and resolution high enough to improve the reconstruction of past sea level oscillations.

In the Gulf of Lion (GoL) margin, western Mediterranean Sea, deltaic forced Regressive Progradational Units (RPUs) stacked on the outer-shelf and upper slope during relative sea-level falls (Fig. 1), led some authors to describe this margin as a forced regressive system (Posamentier et al., 1992; Tesson et al., 1990, 2000). The significant subsidence rate of the margin, $250 \mathrm{~m} \mathrm{Myr}^{-1}$ at the shelf edge (Rabineau, 2001), eased the preservation of RPUs in the upper slope, as it was continuously submerged even during pronounced lowstands. These significant subsidence rate allowed preserving the majority of the regressive/transgressive depositional sequences across the outer shelf (former coastal deposits from old lowstand coast lines) and the upper slope accumulation where dating is easier, thus, resulting in an ideal area for the study of the late Quaternary sedimentary succession. The huge amount of seismic reflection profiles obtained in the GoL margin facilitated the identification of major unconformities defining sequence boundaries in the outer-shelf that become correlative conformities in the upper slope. There five major RPUs were identified and interpreted to correspond to the last five 100-kyr cycle sea level falls (Fig. 1b) (Bassetti et al., 2008; Rabineau et al., 1998, 2005). However, precise dating of RPUs sequence boundaries was still needed to constrain better the imprint of sea-level oscillations on the GoL margin and to determine the leading cyclicity of the deposition of those units, i.e., if they originated during sea-level lowerings of $20 \mathrm{kyr}$ or $100 \mathrm{kyr}$ cycles (Lobo et al., 2004).

In addition, millennial-scale sea-level oscillations at times of rapid climate change during Marine Isotope Stage (MIS) 3 are of special interest, since determining their amplitude and phasing with ice core records is crucial to understand the behaviour and role of ice sheets on millennial climate variability (Siddall et al., 2008). In fact, MIS 3 relative sea-level rises have been tentatively associated with both contributions from the Antarctic and the Laurentide ice sheets (Arz et al., 2007; Rohling et al., 2008; Siddall et al., 2003, 2008; Sierro et al., 2009), thus, evidencing the lack of consensus on the sea-level response to rapid climate variability.

Here, we present grain-size and geochemical records from a borehole in the GoL upper slope, together with a robust oxygen isotope chronostratigraphy, which allow identifying and accurately dating the main RPUs of the last $500 \mathrm{ka}$, and obtaining the timing of millennial-scale sea-level changes in response to abrupt climate variability during MIS 3.

\section{Setting and present day conditions}

The GoL forms a crescent-shaped passive margin that is characterised by a $70 \mathrm{~km}$ wide continental shelf covering an area of about $11000 \mathrm{~km}^{2}$ (Fig. 1a). The GoL continental shelf was mainly built by late Quaternary glacio-eustatic oscillations and post late glacial sedimentation. The shelf can be subdivided in three distinct parts: (i) the inner shelf, extending from 0 to $90 \mathrm{~m}$, is characterised by gradual and regular morphological gradients, as illustrated by parallel and regularly spaced isobaths; the inner shelf corresponds to the modern deltaic prism (Fig. 1); (ii) the middle shelf, ranging in depths from 90 to $110-120 \mathrm{~m}$, is mostly flat with an irregular morphology, mainly capped by relict offshore sands shoals; and (iii) the outer shelf, a narrow band with depths ranging from $110-120 \mathrm{~m}$ that extends to the shelf break and is characterised by a general smooth morphology (Berné et al., 2004a) (Fig. 1a). The shelf break is located at $120-150 \mathrm{~m}$ and is indented by numerous submarine canyons and gullies which connect the continental shelf to the deep margin and basin. The overall GoL continental shelf physiography offered a huge accumulation space for water and sediment storage during periods of relative rising and high sea level during late Quaternary deglacial and interglacial intervals, while it remained totally or partly exposed subaerially during late Quaternary sea-level lowerings and lowstand glacial periods.

The Rhone River is the main source of sediment to the GoL shelf while other minor fluvial inputs also occur along the coastline (Pont et al., 2002). Modern fluvial sediments are mainly trapped on the inner shelf, although they can also be remobilised and subsequently transported to the middle and outer shelf and beyond to the upper slope by shelf erosional and re-suspension processes. These processes are mainly driven by dense shelf water formation and cascading events (DSWC) and easterly storms and, to a much lesser extent, by the southwestward general circulation pattern of the Northern Current (NC) (Fig. 1a) (Bassetti et al., 2006; Canals et al., 2006; Dufois et al., 2008; Ulses et al., 2005). In addition to northerly wind-induced DSWC, deep-water formation also occurs offshore during windy winters, where it may lead to deep convection (Millot, 1999). However, the sediment load involved in offshore convection is very low when compared to DSWC and major coastal storms, both constituting the most effective processes of sediment export from the shelf to the basin, mainly through submarine canyons (Canals et al., 2006; Palanques et al., 2006; Pasqual et al., 2010; Sanchez-Vidal et al., 2008, 2012).

\section{Material and methods}

This study is based on detailed analyses of the $300 \mathrm{~m}$-long continuous sediment record recovered in borehole PRGL1$4\left(42^{\circ} 41.39^{\prime} \mathrm{N}\right.$ and $\left.03^{\circ} 50.26^{\prime} \mathrm{E}\right)$, drilled at $298 \mathrm{~m}$ of water 


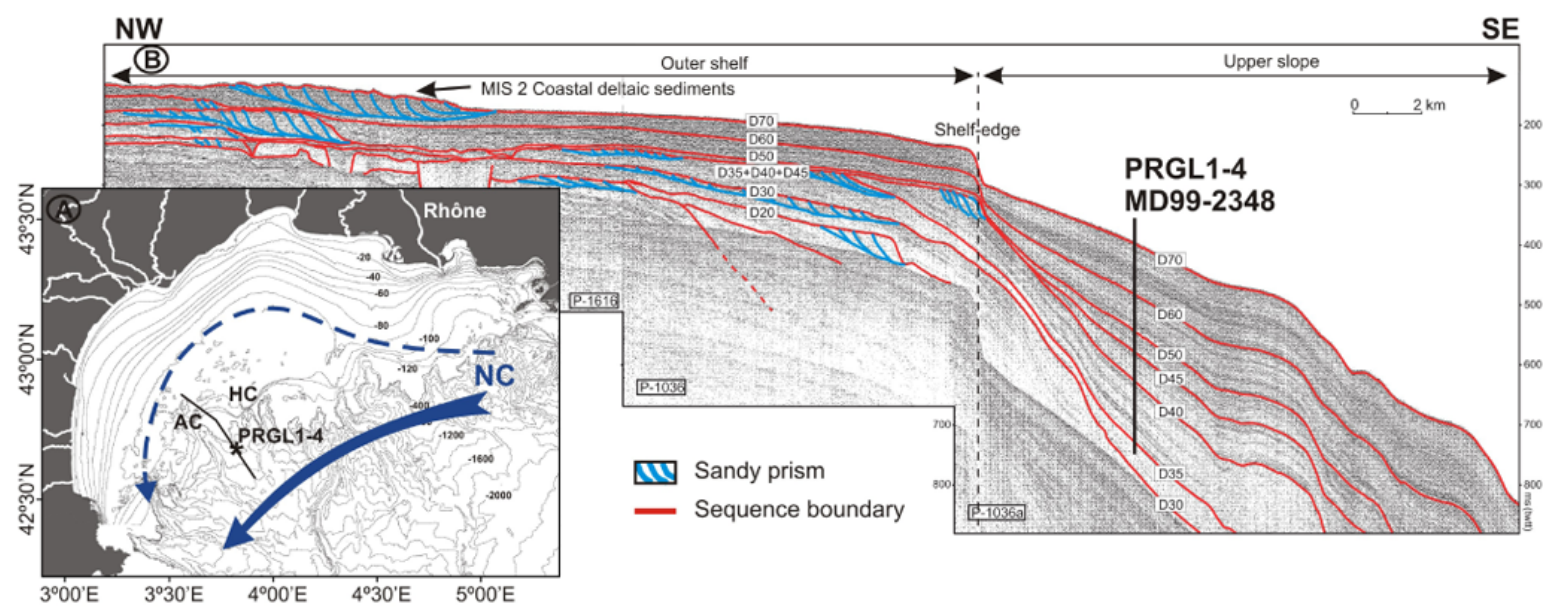

Fig. 1. (A) Bathymetric map of the Gulf of Lion with location of borehole PRGL1-4 in the interfluve separating Aude and Hérault submarine canyons, AC and HC, respectively. The dominant component of the general circulation is shown by the geostrophic Northern Current (NC), which flows southwestward along the slope and occasionally penetrates over the outer shelf, blue arrows. (B) Part of high-resolution seismic reflection profile P-1036a crossing the borehole location in a NW-SE direction across the outer shelf and upper slope (modified from Jouet, 2007). Stratigraphic sequences S1 to S5 delimited by main reflectors D35 to D70 marked as defined by Jouet (2007). Red reflectors show the main conformities separating RPUs while the blue ones correspond to sandy prisms.

depth in the interfluve separating Aude and Hérault submarine canyons during $M V$ Bavenit PROMESS1 cruise, and on the overlapping $22.77 \mathrm{~m}$ long IMAGES core MD99-2348 retrieved at the same location (Fig. 1a).

Grain-size analyses on the bulk and the decarbonated sediment fractions were carried out at $20 \mathrm{~cm}$ sampling intervals with a Coulter LS 100 Laser Particle Size Analyser after removing organic matter by treatment with excess $\mathrm{H}_{2} \mathrm{O}_{2}$ and carbonates by treatment with $\mathrm{HCl}$. Grain-size results are discussed here as the silt/clay ratio of the carbonate-free fraction, an established proxy for energy levels at the time of particle deposition (Frigola et al., 2007). Matching of silt/clay ratio records from both bulk and decarbonated sediments allows discarding the in situ paleoproductivity signal that could affect the grain-size record (Fig. 2b).

Semi-quantitative analysis of major elements $(\mathrm{Ca}, \mathrm{Fe}, \mathrm{Ti}$ and $\mathrm{K}$ ) was carried out at $4 \mathrm{~cm}$ resolution using the first generation Avaatech non-destructive X-ray fluorescence (XRF) core scanner of the University of Bremen. The good correlation of the $\mathrm{Ca}$ record with sedimentation rates and with the clay content (not shown here), suggest that Ca delivery at the study site is mainly related to detrital carbonate inputs from fluvial sources. Calcite is at present one of the main mineralogical components in suspended matter delivered by the Rhône River (Pont et al., 2002), which is the most relevant sediment source to the GoL, as previously mentioned. These evidences support the use of the Ca record from borehole PRGL1-4 as a trustable proxy of changes in fluvial sediment delivery to the GoL upper slope (Fig. 2c).

The age model was obtained by synchronizing the records of planktic Globigerina bulloides $\delta^{18} \mathrm{O}$ and abundance of temperate to warm planktic foraminifers to the North GRIP ice core isotope record for the last $100 \mathrm{ka}$ (Andersen et al., 2006; NGRIP, 2004; Svensson et al., 2008). From 100 to $530 \mathrm{ka}$ the age model was built by aligning the PRGL1-4 G. bulloides $\delta^{18} \mathrm{O}$ record to the LR04 benthic isotope stack (Lisiecki and Raymo, 2005) (Fig. 3), with the support of the planktic oxygen isotope records from the Portuguese margin (Roucoux et al., 2006) and the North Atlantic region (Stein et al., 2009) for specific time intervals. For more details on the age model, tie points and ${ }^{14} \mathrm{C}$-AMS dates see Sierro et al. (2009). Work is in progress to further improve time constrains during MIS 12 and 13 (F. J. Sierro, personal communication, 2012). Temporal variability of sedimentation rates (SR) resulted in a mean temporal resolution of 160 and $1550 \mathrm{yr}$ during glacial and interglacial periods, respectively.

\section{Results and discussion}

\subsection{The orbital 100-kyr sea-level imprint}

The silt/clay ratio and Ca records from PRGL1-4 show a seesaw pattern defining five main units characterised by an upwards fining and $\mathrm{Ca}$ content increasing trend, which can be correlated with the main seismostratigraphic units in the seismic reflection profiles crossing the borehole location (Jouet, 2007) (Fig. 2). The sedimentary units end with an abrupt increase in the silt/clay ratio and a rapid decrease in the $\mathrm{Ca}$ content coinciding with the main reflectors corresponding to sequence boundaries in the seismic reflection profile. The excellent correlation of these analytical sequences with the seismostratigraphy, together with chronostratigraphic control from the G. bulloides $\delta^{18} \mathrm{O}$ record (Sierro et al., 2009), 


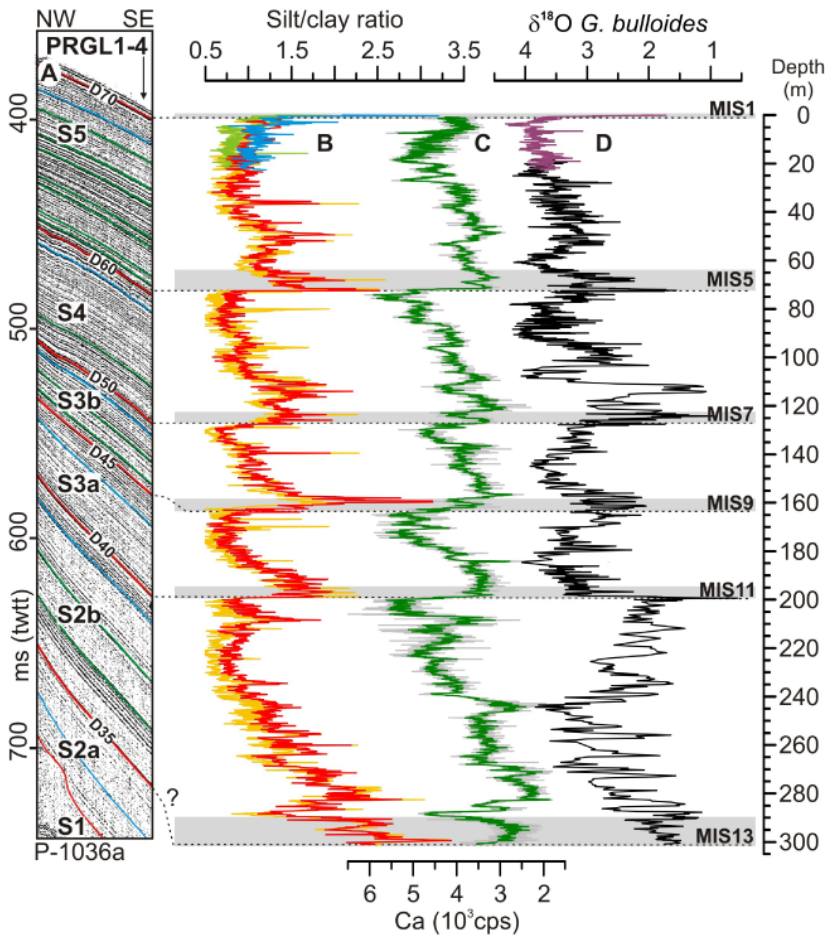

Fig. 2. (A) Close view of high-resolution seismic reflection profile P-1036a at the location of borehole PRGL1-4 (Jouet, 2007), visually correlated with (B) silt/clay ratio records from total (light orange and green) and $\mathrm{Ca}$-free (red and blue) sediment fractions from PRGL1-4 and MD99-2348 sediment cores, respectively. (C) 5-point moving average (green) of Ca record (grey) from PRGL14. (D) Oxygen isotopic records from PRGL1-4 (black) and MD992348 (purple) obtained from G. bulloides. Grey bars correspond to condensed interglacials sequences $1,5,7,9,11$ and 13. Dotted lines correlate the main seismic reflectors (sequence boundaries) and their expression on the different records.

confirm the 100-kyr-cycle origin of these units. The data derived from PRGL1-4 borehole allowed us to reinterpret the seismostratigraphy of the GoL upper slope, where seven units (S1, S2a, S2b, S3a, S3b, S4 and S5) are now documented (Jouet, 2007), instead of the five (S1 to S5) previously identified from seismic reflection profiles alone (Rabineau, 2001). These seven units result from subdividing the former sequences S2 and S3 into S2a and S2b, and S3a and S3b, respectively (Fig. 2a). The results obtained suggest that the lowermost seismostratigraphic units S1 and S2a were not penetrated at PRGL1-4, with the base of the drill most likely corresponding to MIS 13 taking into account extinction of coccolith P. lacunosa at about $275 \mathrm{~m}$ in the borehole (Figs. 2 and 3). Accordingly, the upper five main depositional sequences stacked on the upper slope of the GoL, corresponding to RPUs driven by global sea-level oscillations of the last five glacial cycles, are identified in the continuous sedimentary record of PRGL1-4 borehole. Consequently, abrupt increases in the silt/clay ratio and decreases in the $\mathrm{Ca}$ content respond to rapid sea level rise, continental shelf flooding and subsequent landward migration of deltaic systems during glacial-interglacial transitions, giving birth to sequence boundaries in the upper slope as defined by analytical results (Fig. 2).

RPU stacking in the upper slope resulted from seaward migration of deltaic systems and the subsequent enhancement of riverine supply because of the sea level lowering during each $100-\mathrm{kyr}$ cycle. That is why maximum sedimentation rates $\left(1.5-2.5 \mathrm{~m} \mathrm{kyr}^{-1}\right)$ in the upper slope were recorded during periods when the distance to river mouths was minimal (i.e., during glacial lowstands) (Figs. 3g and 4a). The presence of relict offshore sands at $110-115 \mathrm{~m}$ depth along the outermost shelf further supports the location of lowstand glacial paleo-shorelines in the vicinity of the Aude Canyon head (Aloïsi, 1986; Bassetti et al., 2006; Berné et al., 2004a; Jouet et al., 2006). The increasing trend of SRs linked to sea level lowering across a glacial period is particularly well resolved for the last glacial period (MIS 2, 3 and 4), during which intervals the chronostratigraphic control is particularly robust (Fig. 3g). Sedimentation rates also peaked during previous 100 -kyr cycles glacial sea level minima, although the weaker chronostratigraphic control with depth does not allow distinguishing SR trends during previous full forced regressions, but only low or high SR during interglacial and glacial stages, respectively. Co-occurrence of lowest silt/clay ratios and highest $\mathrm{Ca}$ contents during glacial sea level minima confirms the reinforced influence of nearby glacial river mouths on the sedimentation of fines over upper slope interfluves (Fig. 3d and f). Accordingly, while during glacial lowstands the coarsest fractions were mostly trapped and funnelled by glacial adjacent submarine canyons, as demonstrated by pronounced axial incisions within their upper courses (Baztan et al., 2005), large amounts of fine particles supplied by the nearby river mouths remained in suspension, probably transported by along shore current and un-trapped by the canyons, thus, leading to substantial accumulation in inter-canyon areas.

In contrast, SRs were lowest $\left(0.10-0.25 \mathrm{~m} \mathrm{kyr}^{-1}\right)$ during interglacial sea-level highstands associated with the landward migration of deltaic systems far away from the shelfbreak and upper slope (Figs. 3g and 4b), as illustrated by the modern Holocene epicontinental prism extending down to $90 \mathrm{~m}$ water depth over the inner shelf (Aloïsi, 1986; Berné et al., 2007, 2004b). Obviously, these glacial/interglacial contrasting sedimentation rates resulted in expanded glacial intervals (therefore, resulting in higher temporal resolution) and condensed interglacial intervals down the $500 \mathrm{kyr}-$ long record in PRGL1-4 borehole (Fig. 3). With each sea level rise, sedimentation rates reduce significantly in the upper slope and PRGL1-4 records experience a reduction of temporal resolution (e.g., just few points represent a full interglacial period). This same limitation in time resolution prevents us to establish the exact timing of SR reductions, which in turn are depending on selection of tie points in the age model. In 


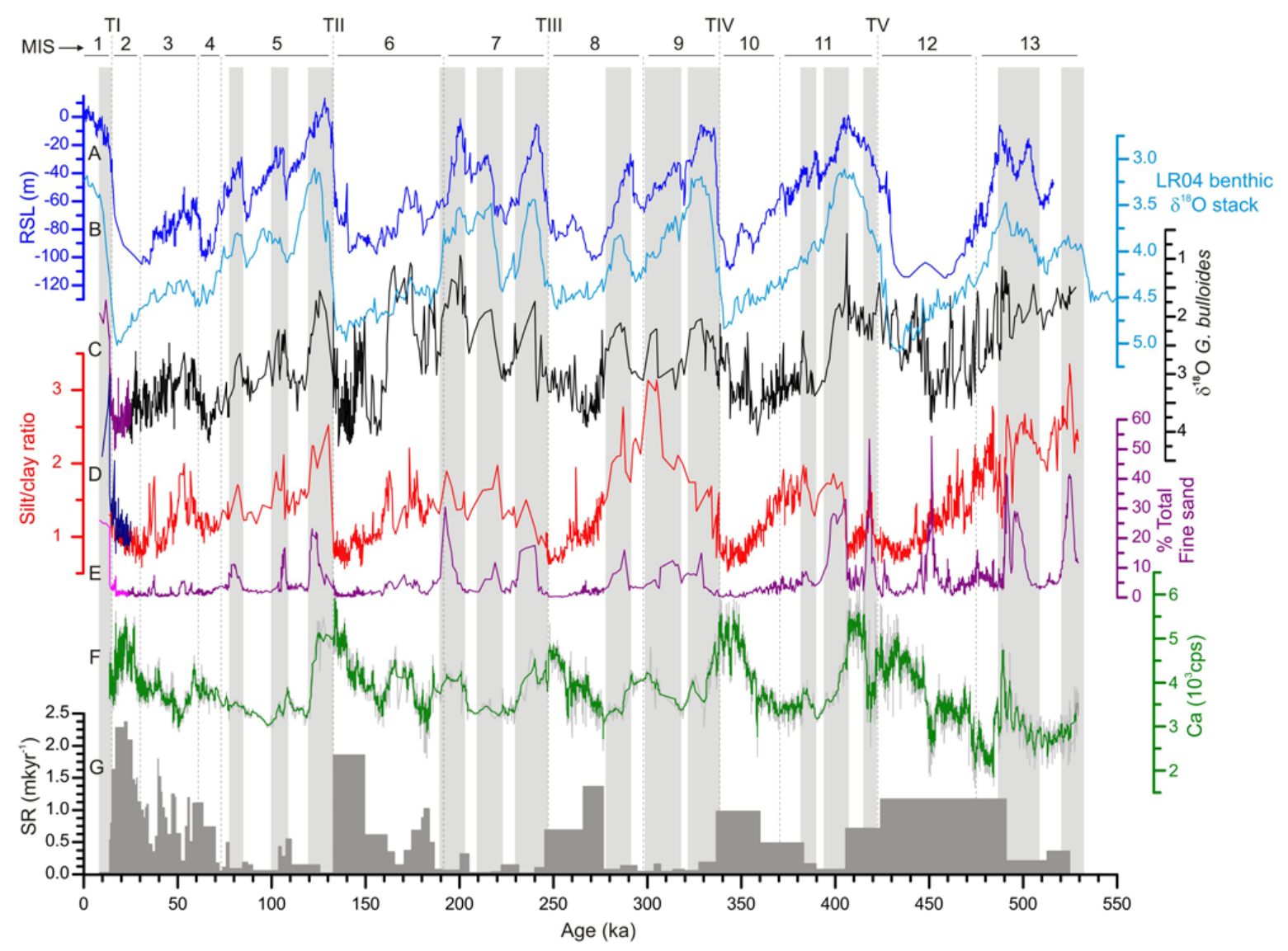

Fig. 3. Multiproxy continuous records of PRGL1-4 borehole with respect to relative sea-level oscillations for the last 500 ka. (A) Composite central Red Sea relative sea level reconstruction for the last $500 \mathrm{ka}$ (Rohling et al., 2009). (B) LR04 benthic isotope stack record used as reference record (Lisiecki and Raymo, 2005). PRGL1-4 records of (C) G. bulloides $\delta^{18} \mathrm{O}$, (D) Ca-free silt/clay ratio, (E) total fine sand (\%) (Sierro et al., 2009), (F) XRF-Ca, and (G) linear sedimentation rates. The top $22 \mathrm{ka}$ of the G. bulloides $\delta^{18} \mathrm{O}$ record (purple), the silt/clay ratio of the carbonate-free fraction (blue) and the total fine sand (pink) are from overlapping core MD99-2348, which include the abrupt change associated with the last deglaciation that is not covered by the XRF-Ca record of PRGL1-4. Vertical grey bars show how the main condensed layers (CLs), defined by abrupt increases in the total fine sand fraction record, fit with interglacial stages.

addition, the very low SRs during the main interglacial highstands led to the formation of condensed layers (CLs), i.e., sandy layers rich in pelagic skeletal material, along the GoL upper slope (Fig. 3e), as shown by the total (bulk fraction, non carbonate-free) fine sand record of Sierro et al. (2009) (Fig. 3e).

However, the landward excursion of deltaic systems linked to the updip migration of the coastline when sea level rise is rising and the associated reduction in sediment flux to the upper slope during glacial/interglacial transitions, cannot explain the continuous supply of coarse particles to the upper-slope during every interglacial stage, as evidenced by the high values of the carbonate-free silt/clay ratio (Fig. 3d), nor the observed increase in non-biogenic sand particles (mainly quartz grains) into the sediment. These results suggest that the interglacial flooding of the $70 \mathrm{~km}$ wide $\mathrm{GoL}$ shelf (Fig. 4b) likely reactivated oceanographic processes able to erode, re-suspend and transport coarse particles, like those contributing to the formation of CLs. While the southwards flowing Northern Current (NC) sweeping the shelf edge and upper slope (Fig. 1a) could contribute winnowing the finest particles during long lasting periods of reduced sediment input to the upper slope, it could not explain the arrival of new lithic coarse material found in deposits formed during interglacial periods, including CLs. The inundation of the shelf during interglacial periods generated a relatively thin layer of water that was highly sensitive to atmospheric forcing, which may trigger the remobilisation of sedimentary particles temporarily stored on the shelf, as it happens during the present day highstand (Bassetti et al., 2006; Canals et al., 2006; Dufois et al., 2008). Recent studies have demonstrated that nowadays northern cold, strong and persistent winds lead to DSWC down-slope at high speed (up to $1 \mathrm{~m} \mathrm{~s}^{-1}$ or more) during late winter and early spring months in the GoL (Canals et al., 2006). Cascading waters carry large amounts of organic matter and sedimentary particles whose 


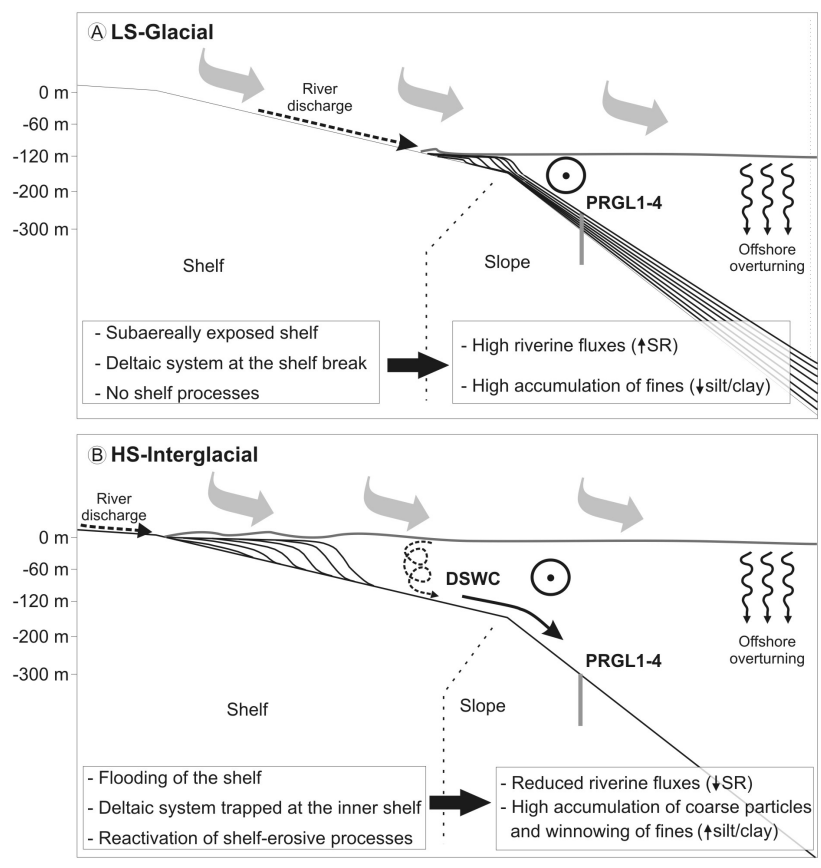

Fig. 4. Conceptual depositional model of the Gulf of Lion continental margin at orbital scale. (A) During the lowstand (LS) depositional mode (glacial periods) the continental shelf is subaerially exposed and the basinwards migration of deltaic system results in high amounts of fine particles supplied directly to the upper slope. (B) Flooding of the shelf during the high-stand (HS) depositional mode (interglacial periods) traps deltaic systems in the inner shelf, thus, disconnecting the upper slope from direct fluvial discharges. Moreover, the creation of a relatively thin layer of water over the continental shelf reactivates shelf erosive processes, such as Dense Shelf Water Cascading (DSWC), that are able to transport coarse particles down the slope. Both processes contribute to generate thin condensed layers (CLs) in the upper slope. Grey arrows represent the northern winds involved in cooling the superficial shelf water for dense shelf water formation and offshore overturning. Dot in a circle shows the dominant direction of the slope-parallel Northern Current. The discontinuous spiral arrow over the shelf represents shelf-erosive processes, as DSWC.

coarser fraction efficiently scours and erodes the shelf edge and canyon heads and upper courses (Gaudin et al., 2006; Lastras et al., 2007; Pasqual et al., 2010; Puig et al., 2008; Sanchez-Vidal et al., 2008). Activation in the past of continental shelf erosive processes like DSWC probably did not lead to significant sediment accumulation in upper slope interfluves, but favoured the winnowing of fines and the supply of coarse lithic particles that, in combination with low sedimentation rates, contributed to generate CLs. When the "cooling platform" disappeared, i.e., during subaerial exposure of the continental shelf (lowstand conditions, Fig. 4a), there was no room left for dense shelf waters to form and, therefore, these type of continental shelf erosive processes ceased. During transitional periods, when the shelf was partly flooded, the volume of water involved in cascading and other continental shelf erosive processes was smaller, subsequently lessening downslope transport by dense shelf waters. Therefore, changes in the silt/clay ratio also respond to the flooded shelf area and, consequently, to sea-level oscillations. This explains the relatively good match between the silt/clay ratio and sea level for the last $500 \mathrm{ka}$ (Fig. 3a and d), which is especially evident for the last glacial cycle when the chronostratigraphic control is more precise. Obviously, the silt/clay ratio did not respond linearly to sea-level oscillations and reactivation of continental shelf erosive processes could be also related to some environmental threshold, e.g., the volume of water stored on the shelf. This, together with significant reductions of SRs during each sea level rise, and subsequent reductions in time resolution, prevent us using the silt/clay ratio as an exact indicator of the beginning of sea level rises. However, the persistent pattern observed in the silt/clay ratio through the last five glacial/interglacial cycles and also at millennial time scales, as described below, confirms this ratio is a good indicator of relative high sea-level conditions (highstands) in the GoL margin.

These results support a combined shelf and upper slope depositional model for inter-canyon RPU stacking over the last $500 \mathrm{ka}$ that considers two main processes: (i) oscillations in sediment supply due to the migration of river mouths and deltaic systems, and (ii) activation-deactivation of continental shelf erosive processes like DSWC, both of them ultimately driven by the $100-\mathrm{kyr}$ glacio-eustatic cyclicity (Fig. 4).

\subsection{The millennial MIS 3 sea level imprint}

Since this combined depositional model has been tested at glacial/interglacial scales, it is reasonable to expect that minor scale sea-level oscillations would also result in a similar sedimentary signature in the GoL margin outbuilding. Considering the passive character of the margin, the flatness and width of the GoL shelf, and the robust chronostratigraphic framework for the last glacial cycle (i.e., excellent synchronization between the PRGL1-4 G. bulloides $\delta^{18} \mathrm{O}$ record and the NGRIP ice core record, Fig. 5a and b) due to elevated SRs (ranging from 0.2 to $2 \mathrm{~m} \mathrm{kry}^{-1}$ ), the PRGL1-4 record could be highly valuable for disentangling the millennial scale sea level variability during MIS 3. Independently of chronologies, the exhaustive compilation of MIS 3 sea-level reconstructions by Siddall et al. (2008) shows two common patterns of variability: (1) the mean sea level during the first half of MIS 3 was approximately $20 \mathrm{~m}$ higher than in the second half, and (2) four 20-30 m-amplitude millennial-scale sea-level fluctuations occurred during this period (Fig. 5e). These features are also observed in the PRGL1-4 silt/clay record (Fig. 5c), thereby demonstrating that the GoL system responded to both long and short-term sea-level fluctuations during MIS 3. 


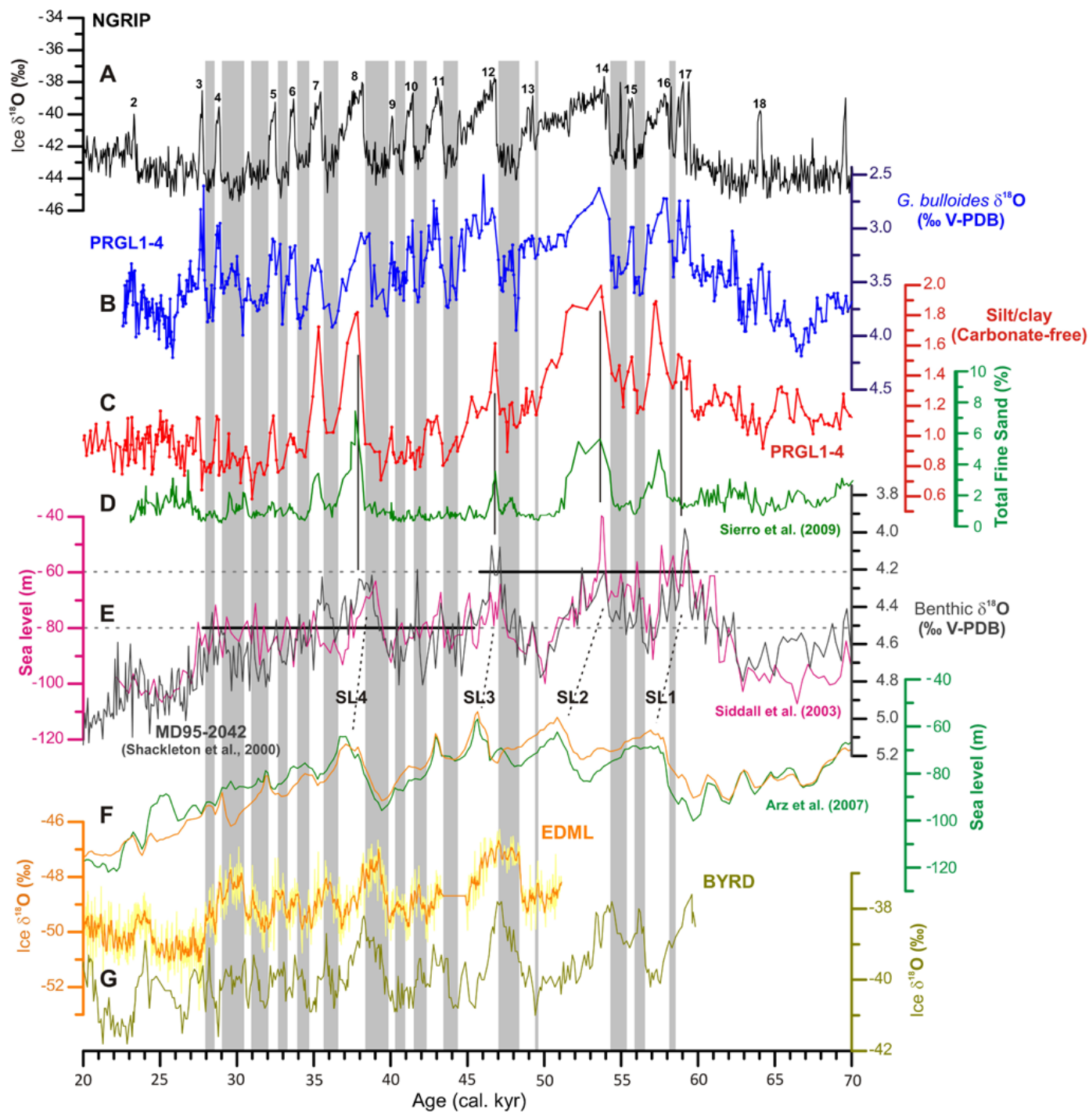

Fig. 5. Comparison of different records of climate variability and sea-level reconstructions for the MIS 3 period, all of them age-scaled to the Greenland ice core NGRIP (Svensson et al., 2008) (A). (B) G. bulloides oxygen isotopic record (blue), (C) carbonate-free silt/clay ratio (red) and (D) total fine sand fraction (green) from PRGL1-4 borehole. (E) Benthic oxygen isotopic record from MD95-2042 (Shackleton et al., 2000) (dark grey) compared to Red Sea sea level reconstruction (Siddall et al., 2003) (pink), with horizontal lines showing that mean sea level was $\sim 20 \mathrm{~m}$ higher in early MIS 3 than in late MIS 3. Discontinuous lines point four millennial-scale peaks of relative high sea level (SL1, 2, 3 and 4). (F) Sea level reconstructions from the northern Red Sea based on two different temperature corrections for the deep basin (Arz et al., 2007). (G) Oxygen isotopic records from Antarctic ice cores EDML and BYRD (Blunier and Brook, 2001; EPICA Community Members, 2006) $\mathrm{CH}_{4}$-synchronized to Greenland ice core NGRIP (Svensson et al., 2008). Numbers above the NGRIP record represent warm GIS, while vertical grey bars correspond to cold GS and HE.

The general decreasing trend observed in the PRGL1-4 silt/clay ratio during the progressive sea level lowering of the last glacial cycle (Fig. 3), is punctuated by a series of grainsize increases (Fig. 5c), which suggest that millennial-scale relative sea level rises occurred during MIS 3. By temporally extending the flooded area of the GoL shelf, MIS 3 relative sea level rises reduced the clay supply to the upper slope and contributed to expose a larger volume of water to atmospheric forcing, eventually leading to DSWC and, hence, indirectly reinforcing the transport of coarse particles to the upper slope. Both mechanisms contributed to increases in the silt/clay ratio (Fig. 5c). Those grain-size increases are unrelated to periods of intensification of deep-water formation in the GoL, since most of them occurred during relatively warm Greenland interstadials (GIS) (Fig. 5b and c), in contrast with observations of enhanced Western Mediterranean Deep Water (WMDW) formation during MIS 3 cold Greenland Stadials (GS) (Cacho et al., 2000, 2006; Frigola et al., 2008; Sierro et al., 2005). 
Confirming or discarding the occurrence of sea-level oscillations at Dansgaard-Oeschger (D-O) scale has been prevented so far because none of the existing sea-level records was able to resolve variations lower than $12 \mathrm{~m}$ in amplitude during time intervals as short as $1 \mathrm{kyr}$ (Siddall et al., 2008). Nevertheless, prominent increases in iceberg calving during cold Greenland stadials (GS) (non Heinrich Events, HE) suggest that sea level should have oscillated within each D-O cycle (Bond and Lotti, 1995; Chappell, 2002; Siddall et al., 2008; van Kreveld et al., 2000). Disentangling MIS 3 sealevel variability also faces the difficulty of establishing the absolute timing of the observed oscillations, which is necessary to understand the role of sea level in millennial-scale climate variability during MIS 3 and to determine the relative contribution of "northern" versus "southern" sources (Clark et al., 2007).

Early evidence of millennial-scale sea-level variability was obtained from the benthic $\delta^{18} \mathrm{O}$ record of the Portuguese margin core MD95-2042 (Shackleton et al., 2000) and sealevel reconstruction from the Red Sea (Siddall et al., 2003) (Fig. 5e). Although the Portuguese record may be influenced by oscillations in deep ocean temperature and local hydrographic variability, an important part of the record is linked to global sea level change (Skinner et al., 2007). Since both records display a variability pattern that is remarkably similar to the one found in Antarctic ice cores (Fig. 5e and g), it has been suggested that MIS 3 sea-level oscillations followed Antarctic climate variability (Rohling et al., 2008; Siddall et al., 2003). Contrary to these interpretations, recent results from the Red Sea and the GoL have shown millennial-scale sea level rises to occur during major warm Greenland interstadials (GIS) (Fig. 5f and d) (Arz et al., 2007; Jouet et al., 2012; Sierro et al., 2009), further highlighting the still high uncertainty about the timing of MIS 3 sea-level variability.

The co-occurrence of silt/clay increases and planktic $\delta^{18} \mathrm{O}$ depletions in the PRGL1-4 record (Fig. 5b and c) imply, independently of the age model applied, that relative high sea levels occurred during warm GIS events. Concurrently, Shackleton et al. (2000) and Siddall et al. (2003) records also show maximum sea levels to occur during the onset phase of major GIS interstadials (i.e., GIS14, 12 and 8) (Fig. 5a and e). However, discrepancies on the precise timing of the sea level rises exist with our PRGL1-4 record. The excellent time constrains provided by the G. bulloides $\delta^{18} \mathrm{O}$ record of the PRGL1-4 borehole demonstrate a consistent peak to peak coupling between sea-level variability (as indicated by increases in the silt/clay ratio) and all D-O cycles, including the shortest ones. Nevertheless, not every relative high sea level resulted in the formation of CLs, since these were only observed during major GIS $(16,14,12,8$ and 7) (Sierro et al., 2009), all of which coincide with higher values of the silt/clay ratio (Fig. $5 \mathrm{c}$ and d). The differences between the total fine sand record of Sierro et al. (2009) and our silt/clay ratio indicate that sea level increases during minor GIS (15, $13,11,10,9,6,5,4$ and 3 ) were likely not high and/or long enough to generate CLs, therefore, demonstrating once more the strong sensitivity of the silt/clay ratio to sea-level oscillations. The great sensitivity of the silt/clay ratio during MIS 3 could be also related to the fact that sea level was oscillating between $-60 \mathrm{~m}$ and $-80 \mathrm{~m}$, when the continental shelf was not fully exposed and prodeltaic deposits could be close to equilibrium with the accommodation space over the shelf.

A limitation of the PRGL1-4 silt/clay record is that the amplitude of sea level variations cannot be directly derived, as nowhere has it been shown that grain-size oscillations respond linearly to sea-level fluctuations. This very same limitation, and reduction of PRGL1-4 time resolution due to decreasing SRs with sea level increases, also prevents setting up the precise timing of sea level rises, whether they occurred at the beginning of each warm GIS or during the previous cold stadial. This relates to the exact timing of deltaic migration and their relative position following sea-level rise. In addition, the enhanced supply of coarse particles by reactivation of continental shelf erosive processes, such as DSWC, should normally occur some time after the start of each sealevel rise, i.e., when the volume of water over the shelf is again large enough.

Our results imply that sea-level was relatively high during all warm GIS within MIS 3 (Fig. 5a and c), although intrinsic limitations of the methodology applied in this study do not allow establishing the precise time nor the mechanisms involved in such millennial scale sea level rises, which could initiate by instabilities and melting of continental ice-sheets during cold GS, whether or not they correspond to HEs.

\section{Conclusions}

The last $500 \mathrm{ka}$ continuous sediment record of the $300 \mathrm{~m}$ long PRGL1-4 borehole drilled in the upper slope of the river fed GoL holds the imprint of sea-level oscillations at orbital and millennial time scales during MIS 3. The sedimentary succession of PRGL1-4 consists of five regressive progradational units (more aggradational on the upper slope) that relate to the glacio-eustatic 100-kyr cyclicity. The consistent chronostratigraphy of the investigated section and the good matching between seismic reflection profiles and the grainsize record provide clues for understanding the nature of seismic reflections in mud-dominated slope sequences like the ones found at the investigated site, and also provides a tool to identify the boundaries of seismostratigraphic units while helping to tie them with global sea-level oscillations. These findings have resulted in the reinterpretation of the stratigraphy of the upper slope in the GoL, following an approach that can be extended to similar continental margin settings.

In addition of pushing the shoreline and associated sedimentary environments landwards, thus, disconnecting the upper slope from direct riverine sediment sources, we propose that sea level rise can reactivate transient energetic hydrosedimentary processes, such as DSWC, which are able of 
eroding, resuspending and transporting significant volumes of sediment from the continental shelf and upper slope to the deep basin. The sedimentary starvation of the upper slope during highstands, jointly with both episodic and persistent hydrodynamic processes winnowing the fine fraction, determined the formation of CLs that mark the periods of continental shelf flooding during interglacial epochs, as evidenced by our grain-size records.

Finally, the excellent match of the PRGL1-4 silt/clay record with previous records of sea-level variability at millennial-scale during MIS 3, together with the good time constraint provided by the G. bulloides $\delta^{18} \mathrm{O}$ record, strongly support the occurrence of relatively high sea levels during each single warm GIS, even the smallest ones. Unfortunately, the precise starting time of sea level rises cannot be established solely from the sediment record of the GoL upper slope, which points to the need of further devoted research to resolve the origin and magnitude of MIS 3 sea-level variability.

Acknowledgements. This study has been supported by the EC PROMESS1 (EVR1-CT-200240024) and HERMIONE (226354HERMIONE) projects, and the Spanish GRACCIE CONSOLIDER (CSD2007-00067) and DOS MARES (CTM2010-21810-C03-01) projects and CGL2005-24147-E complementary action. The IMAGES programme contributed to the research by providing the MD99-2348 sediment core. French partners benefited from additional support by Agence Nationale de la Recherche (ANR, contract NT05-3-42040). We are also grateful for comments and suggestions of reviewers Jamie Austin and Andre Droxler, which helped to improve the manuscript. We thank Anders Sevensson and Thomas Blunier for providing NGRIP and EDML data, respectively. We are especially grateful to PROMESS 1 participating scientists and to the staff of the various laboratories where sediment samples were analysed. We are grateful for the support provided by Fugro Engineers B. V. that made the challenging $M V$ Bavenit cruise a success history. Generalitat de Catalunya recognises CRG Marine Geosciences within its excellence research groups program (ref. 2009 SGR 1305).

Edited by: L. Beaufort

\section{References}

Aloïsi, J. C.: Sur un modèle de sédimentation deltaïque: contribution à la connaissance des marges passives, University of Perpignan, Perpignan, 162 pp., 1986.

Andersen, K. K., Svensson, A., Johnsen, S. J., Rasmussen, S. O., Bigler, M., Rothlisberger, R., Ruth, U., Siggaard-Andersen, M.L., Peder Steffensen, J., Dahl-Jensen, D., Vinther, B. M., and Clausen, H. B.: The Greenland Ice Core Chronology 2005, 15-42 ka. Part 1: constructing the time scale, Quaternary Sci. Rev., 25, 3246-3257, 2006.

Arz, H. W., Lamy, F., Ganopolski, A., Nowaczyk, N., and Patzold, J.: Dominant Northern Hemisphere climate control over millennial-scale glacial sea-level variability, Quaternary Sci. Rev., 26, 312-321, 2007.

Bassetti, M. A., Jouet, G., Dufois, F., Berne, S., Rabineau, M., and Taviani, M.: Sand bodies at the shelf edge in the Gulf of Lions (Western Mediterranean): Deglacial history and modern processes, Mar. Geol., 234, 93-109, 2006.

Bassetti, M. A., Berné, S., Jouet, G., Taviani, M., Dennielou, B., Flores, J. A., Gaillot, A., Gelfort, R., Lafuerza, S., and Sultan, N.: The 100-ka and rapid sea-level changes recorded by prograding shelf sand bodies in the Gulf of Lions (western Mediterranean Sea), Geochem. Geophy. Geosy., 9, Q11R05, doi:10.1029/2007GC001854, 2008.

Baztan, J., Berne, S., Olivet, J. L., Rabineau, M., Aslanian, D., Gaudin, M., Rehault, J. P., and Canals, M.: Axial incision: The key to understand submarine canyon evolution (in the western Gulf of Lion), Mar. Petrol. Geol., 22, 805-826, 2005.

Berné, S., Carré, B., Loubrieu, B., Mazé, J. P., Morvan, L., and Normand, A.: Notice de la carte morpho-bathymétrique du Golfe du Lion, IFREMER, Brest, 2004a.

Berné, S., Rabineau, M., Flores, J. A., and Sierro, F. J.: The impact of Quaternary Global Changes on strata formation. Exploration of the shelf edge in the Northwest Mediterranean Sea, Oceanography, 17, 92-103, 2004b.

Berné, S., Jouet, G., Bassetti, M. A., Dennielou, B., and Taviani, M.: Late Glacial to Preboreal sea-level rise recorded by the Rhone deltaic system (NW Mediterranean), Mar. Geol., 245, 65-88, 2007.

Blunier, T. and Brook, E. J.: Timing of Millennial-Scale Climate Change in Antarctica and Greenland During the Last Glacial Period, Science, 291, 109-112, 2001.

Bond, G. and Lotti, R.: Iceberg discharges into the North Atlantic on millennial time scales during the last deglaciation, Science, 267, 1005-1010, 1995.

Cacho, I., Grimalt, J. O., Sierro, F. J., Shackleton, N. J., and Canals, M.: Evidence for enhanced Mediterranean thermohaline circulation during rapid climatic coolings, Earth Planet. Sc. Lett., 183, 417-429, 2000.

Cacho, I., Shackleton, N., Elderfield, H., Sierro, F. J., and Grimalt, J. O.: Glacial rapid variability in deep-water temperature and $\delta^{18} \mathrm{O}$ from the Western Mediterranean Sea, Quaternary Sci. Rev., 25, 3294-3311, 2006.

Canals, M., Puig, P., de Madron, X. D., Heussner, S., Palanques, A., and Fabres, J.: Flushing submarine canyons, Nature, 444, 354357, 2006.

Clark, P. U., Hostetler, S. W., Pisias, N. G., Schmittner, A., and Meissner, K.: Mechanisms for an 7-kyr climate and sea-level oscillation during Marine Isotopic Stage 3, in: Ocean Circulation: Mechanisms and Impacts, edited by: Schmittner, A., Chiang, J. C. H., Hemming, S. R., AGU Geophysical Monograph Series, Washington DC, 209-246, 2007.

Chappell, J.: Sea level changes forced ice breakouts in the Last Glacial cycle: new results from coral terraces, Quaternary Sci. Rev., 21, 1229-1240, 2002.

Dufois, F., Garreau, P., Le Hir, P., and Forget, P.: Wave- and currentinduced bottom shear stress distribution in the Gulf of Lions, Cont. Shelf Res., 28, 1920-1934, 2008.

EPICA Community Members: One-to-one coupling of glacial climate variability in Greenland and Antarctica, Nature, 444, 195198, 2006. 
Frigola, J., Moreno, A., Cacho, I., Canals, M., Sierro, F. J., Flores, J. A., Grimalt, J. O., Hodell, D. A., and Curtis, J. H.: Holocene climate variability in the western Mediterranean region from a deepwater sediment record, Paleoceanography, 22, PA2209, doi:10.1029/2006PA001307, 2007.

Frigola, J., Moreno, A., Cacho, I., Canals, M., Sierro, F. J., Flores, J. A., and Grimalt, J. O.: Evidence of abrupt changes in Western Mediterranean Deep Water circulation during the last 50 kyr: A high-resolution marine record from the Balearic Sea, Quaternary Int., 181, 88-104, doi:10.1016/j.quaint.2007.06.016, 2008.

Gaudin, M., Berne, S., Jouanneau, J. M., Palanques, A., Puig, P., Mulder, T., Cirac, P., Rabineau, M., and Imbert, P.: Massive sand beds attributed to deposition by dense water cascades in the Bourcart canyon head, Gulf of Lions (northwestern Mediterranean Sea), Mar. Geol., 234, 111-128, 2006.

Imbrie, J., Boyle, E., Clemens, C., Duffy, A., Howard, W., Kukla, G., Kutzbach, J. E., Martinson, D. G., McIntyre, A., Mix, A. C., Molfino, B., Morley, J. J., Peterson, L. C., Pisias, N. G., Prell, W., Raymo, M. E., Shackleton, N. J., and Toggweiler, J. R.: On the structure and origin of major glaciation cycles. 1. Linear responses to Milankovitch forcing, Paleoceanography, 7, 701-738, 1992.

Jouet, G.: Enregistrements stratigraphiques des cycles climatiques et glacio-eustatiques du Quaternaire terminal-Modélisations de la marge continentale du Golfe du Lion, PhD Thesis, Laboratoire Environnements Sédimentaires, Géosciences Marines. Ifremer, Brest, France, 443 pp., 2007.

Jouet, G., Berne, S., Rabineau, M., Bassetti, M. A., Bernier, P., Dennielou, B., Sierro, F. J., Flores, J. A., and Taviani, M.: Shoreface migrations at the shelf edge and sea-level changes around the Last Glacial Maximum (Gulf of Lions, NW Mediterranean), Mar. Geol., 234, 21-42, 2006.

Jouet, G., Berné, S., Sierro, F. J., Bassetti, M. A., Canals, M., Dennielou, B., Flores, J. A., Frigola, J., and Haq, B. U.: Geological imprints of millennial-scale sea-level changes, Terra Nova, accepted, 2012.

Lastras, G., Canals, M., Urgeles, R., Amblas, D., Ivanov, M., Droz, L., Dennielou, B., Fabrés, J., Schoolmeester, T., Akhmetzhanov, A., Orange, D., and García-García, A.: A walk down the Cap de Creus canyon, Northwestern Mediterranean Sea: Recent processes inferred from morphology and sediment bedforms, Mar. Geol., 246, 176-192, 2007.

Lisiecki, L. E. and Raymo, M. E.: A Pliocene-Pleistocene stack of 57 globally distributed benthic $\mathrm{d}^{18} \mathrm{O}$ records, Paleoceanography, 20, PA1003, doi:10.1029/2004PA001071, 2005.

Lobo, F. J., Tesson, M., and Gensous, B.: Stratral architectures of late Quaternary regressive-transgressive cycles in the Roussillon Shelf (SW Gulf of Lions, France), Mar. Petrol. Geol., 21, 11811203, 2004.

Miller, K. G., Kominz, M. A., Browning, J. V., Wright, J. D., Mountain, G. S., Katz, M. E., Sugarman, P. J., Cramer, B. S., ChristieBlick, N., and Pekar, S. F.: The Phanerozoic Record of Global Sea-Level Change, Science, 310, 1293-1298, 2005.

Millot, C.: Circulation in the Western Mediterranean Sea, J. Marine Syst., 20, 423-442, 1999.

NGRIP: High-resolution record of Northern Hemisphere climate extending into the last interglacial period, Nature, 431, 147-151, 2004.
Palanques, A., Durrieu de Madron, X., Puig, P., Fabres, J., Guillen, J., Calafat, A., Canals, M., Heussner, S., and Bonnin, J.: Suspended sediment fluxes and transport processes in the Gulf of Lions submarine canyons. The role of storms and dense water cascading, Mar. Geol., 234, 43-61, 2006.

Pasqual, C., Sanchez-Vidal, A., Zúñiga, D., Calafat, A., Canals, M., Durrieu de Madron, X., Puig, P., Heussner, S., Palanques, A., and Delsaut, N.: Flux and composition of settling particles across the continental margin of the Gulf of Lion: the role of dense shelf water cascading, Biogeosciences, 7, 217-231, doi:10.5194/bg-7217-2010, 2010.

Pont, D., Simonnet, J. P., and Walter, A. V.: Medium-term Changes in Suspended Sediment Delivery to the Ocean: Consequences of Catchment Heterogeneity and River Management (Rhône River, France), Estuar. Coast. Shelf S., 54, 1-18, 2002.

Posamentier, H. W. and Vail, P. R.: Eustatic controls on clastic deposition II - sequence and systems tract models, in: Sea-level changes: an integrated approach, edited by: Wilgus, C. K., Hastings, B. S., Kendall, C. G. S. C., Posamentier, H., Ross, C. A., and Van Wagoner, J. C., Society of Economic Paleontologists and Mineralogists, Tulsa, Oklahoma, 125-154, 1988.

Posamentier, H. W., Allen, G. P., James, D. P., and Tesson, M.: Forced regressions in a sequence stratigraphic framework: concepts, examples, and exploration significance, AAPG Bull., 76, 1687-1709, 1992.

Puig, P., Palanques, A., Orange, D. L., Lastras, G., and Canals, M.: Dense shelf water cascades and sedimentary furrow formation in the Cap de Creus Canyon, northwestern Mediterranean Sea, Cont. Shelf Res., 28, 2017-2030, 2008.

Rabineau, M.: Un modèle géométrique et stratigraphique des séquences de dépôts quaternaires de la plate-forme du Golfe du Lion: enregistrement des cycles glacioeustatiques de 100000 ans. Thèse de Doctorat, Université de Rennes 1 and IFREMER, Rennes, 392, p. $392+$ p. 370 , available at: http://archimer. ifremer.fr/doc/00000/331/, 2001.

Rabineau, M., Berné, S., Ledrezen, E., Lericolais, G., Marsset, T., and Rotunno, M.: 3D architecture of lowstand and transgressive Quaternary sand bodies on the outer shelf of the Gulf of Lion, France, Mar. Petrol. Geol., 15, 439-452, 1998.

Rabineau, M., Berne, S., Aslanian, D., Olivet, J.-L., Joseph, P., Guillocheau, F., Bourillet, J.-F., Ledrezen, E., and Granjeon, D.: Sedimentary sequences in the Gulf of Lion: A record of 100,000 years climatic cycles, Mar. Petrol. Geol., 22, 775-804, 2005.

Rohling, E. J., Fenton, M., Jorissen, F. J., Bertrand, P., Ganssen, G., and Caulet, J. P.: Magnitudes of sea-level lowstands of the past 500,000 years, Nature, 394, 162-165, 1998.

Rohling, E. J., Grant, K., Hemleben, C., Kucera, M., Roberts, A. P., Schmeltzer, I., Schulz, H., Siccha, M., Siddall, M., and Trommer, G.: New constrains on the timing of sea-level fluctuations during early to middle isotope stage 3, Paleoceanography, 23, PA3219, doi:10.1029/2008PA001617, 2008.

Rohling, E. J., Grant, K., Bolshaw, M., Roberts, A. P., Siddall, M., Hemleben, C., and Kucera, M.: Antarctic temperature and global sea-level closely coupled over the past five glacial cycles, Nat. Geosci., 2, 500-504, 2009.

Roucoux, K. H., Tzedakis, P. C., de Abreu, L., and Shackleton, N. J.: Climate and vegetation changes 180,000 to 345,000 years ago recorded in a deep-sea core off Portugal, Earth Planet. Sc. Lett., 249, 307-325, 2006. 
Sanchez-Vidal, A., Pasqual, C., Kerhervé, P., Calafat, A., Heussner, S., Palanques, A., Durrieu de Madron, X., Canals, M., and Puig, P.: Impact of dense shelf water cascading on the transfer of organic matter to the deep western Mediterranean basin, Geophys. Res. Lett., 35, L05605, doi:10.1029/2007GL032825, 2008.

Sanchez-Vidal, A., Canals, M., Calafat, A., Lastras, G., PedrosaPàmies, R., Menéndez, M., Medina, R., Company, J. B., Hereu, B., Romero, J., and Alcoverro, T.: Impacts on the deep-sea ecosystem by a severe coastal storm, PLoS ONE, 7, e30395, doi:10.1371/journal.pone.0030395, 2012.

Shackleton, N. J., Hall, M. A., and Vincent, E.: Phase relationships between millennial-scale events 64,000-24,000 years ago, Paleoceanography, 15, 565-569, 2000.

Siddall, M., Rohling, E. J., Almogi-Labin, A., Hemleben, C., Meischner, D., Schmelzer, I., and Smeed, D. A.: Sea-level fluctuations during the last glacial cycle, Nature, 423, 853-858, 2003.

Siddall, M., Chappell, J., and Potter, E.-K.: Eustatic sea-level during past interglacials, in: The climate of past interglacials, edited by: Sirocko, F., Litt, T., Claussen, M., and Sanchez Goñi, M.-F., Elsevier, Amsterdam, 2006.

Siddall, M., Rohling, E. J., Thompson, W. G., and Waelbroeck, C.: MIS 3 sea level fluctuations: data synthesis and new outlook, Rev. Geophys., 46, RG4003, doi:10.1029/2007RG000226, 2008.

Sierro, F. J., Hodell, D. A., Curtis, J. H., Flores, J. A., Reguera, I., Colmenero-Hidalgo, E., Bárcena, M. A., Grimalt, J. O., Cacho, I., Frigola, J., and Canals, M.: Impact of iceberg melting on Mediterranean thermohaline circulation during Heinrich events, Paleoceanography, 20, PA2019, doi:2010.1029/2004PA001051, 2005.

Sierro, F. J., Andersen, N., Bassetti, M. A., Berné, S., Canals, M., Curtis, J. H., Dennielou, B., Flores, J. A., Frigola, J., GonzalezMora, B., Grimalt, J. O., Hodell, D. A., Jouet, G., Pérez-Folgado, M., and Schneider, R.: Phase relationship between sea-level and abrupt climate change, Quaternary Sci. Rev., 28, 2867-2881, 2009.

Skinner, L. C., Elderfield, H., and Hall, M.: Phasing of millennial climate events and Northeast Atlantic deep-water temperature change since $50 \mathrm{kaBP}$, in: Ocean Circulation: Mechanisms and Impacts, edited by: Schmittner, A., Chiang, J. C. H., and Hemming, S. R., AGU Geophysical Monograph Series, Washington DC, 197-208, 2007.

Stein, R., Hefter, J., Grützner, J., Voelker, A., and Naafs, B. D. A.: Variability of surface water characteristics and Heinrichlike events in the Pleistocene midlatitude North Atlantic Ocean: biomarker and XRD records from IODP Site U1313 (MIS 169), Paleoceanography, 24, PA2203, doi:10.1029/2008PA001639, 2009.
Svensson, A., Andersen, K. K., Bigler, M., Clausen, H. B., DahlJensen, D., Davies, S. M., Johnsen, S. J., Muscheler, R., Parrenin, F., Rasmussen, S. O., Röthlisberger, R., Seierstad, I., Steffensen, J. P., and Vinther, B. M.: A 60000 year Greenland stratigraphic ice core chronology, Clim. Past, 4, 47-57, doi:10.5194/cp-4-472008, 2008.

Tesson, M., Gensous, B., Allen, G. P., and Ravenne, C.: Late Quaternary deltaic lowstand wedges on the Rhône continental shelf, France, Mar. Geol., 91, 325-332, 1990.

Tesson, M., Posamentier, H. W., and Gensous, B.: Stratigraphic organization of late pleistocene deposits of the western part of the Golfe du Lion shelf (Languedoc shelf), Western Mediterranean Sea, using high-resolution seismic and core data, AAPG Bull., 84, 119-150, 2000.

Thompson, W. G. and Goldstein, S. L.: Open-System Coral Ages Reveal Persistent Suborbital Sea-Level Cycles, Science, 308, 401-404, 2005.

Thompson, W. G. and Goldstein, S. L.: A radiometric calibration of the SPECMAP timescale, Quaternary Sci. Rev., 25, 3207-3215, 2006.

Ulses, C., Grenz, C., Marsaleix, P., Schaaff, E., Estournel, C., Meulé, S., and Pinazo, C.: Circulation in a semi-enclosed bay under influence of strong freshwater input, J. Marine Syst., 56, 113-132, 2005.

Vail, P. R., Mitchum Jr., R. M., Todd, R. G., Widmier, J. M., Thompson III, S., Sangree, J. B., Bubb, J. N., and Hatleid, W. G.: Seismic stratigraphy and global changes of sea-level, in: Seismic stratigraphy - applications to hydrocarbon exploration, edited by: Payton, C. E., The American Association of Petroleum Geologists, Tulsa, Oklahoma, 49-212, 1977.

van Kreveld, S. A., Sarnthein, M., Erlenkeuser, H., Grootes, P., Jung, S. J. A., Nadeau, M.-J., Pflaumann, U., and Voelker, A.: Potential links between surging ice sheets, circulation changes, and the Dansgaard-Oeschger cycles in the Irminger Sea, 60-18 kyr, Paleoceanography, 15, 425-442, 2000.

Waelbroeck, C., Labeyrie, L., Michel, E., Duplessy, J. C., McManus, J. F., Lambeck, K., Balbon, E., and Labracherie, M.: Sealevel and deep water temperature changes derived from benthic foraminifera isotopic records, Quaternary Sci. Rev., 21, 295-305, 2002.

Yokoyama, Y., Esat, T. M., and Lambeck, K.: Coupled climate and sea-level changes deduced from Huon Peninsula coral terraces of the last ice age, Earth Planet. Sci. Lett., 193, 579-587, 2001. 